\title{
Combined antitumor effects of bee venom and cisplatin on human cervical and laryngeal carcinoma cells and their drug resistant sublines
}

\author{
Goran Gajski, Tamara Čimbora-Zovko, Sanjica Rak, Marko Rožman, Maja Osmak and Vera Garaj-Vrhovac
}

ABSTRACT: In the present study, we investigated the possible combined anticancer ability of bee venom (BV) and cisplatin towards two pairs of tumour cell lines: parental cervical carcinoma HeLa cells and their cisplatin-resistant HeLa CK subline, as well as laryngeal carcinoma HEp-2 cells and their cisplatin-resistant CK2 subline. Additionally, we identified several peptides of BV in the BV sample used in the course of the study and determined the exact concentration of MEL. BV applied alone in concentrations of 30 to $60 \mu \mathrm{g} \mathrm{m} \mathrm{I}{ }^{-1}$ displayed dose-dependent cytotoxicity against all cell lines tested. Cisplatin-resistant cervical carcinoma cells were more sensitive to BV than their parental cell lines $\left(I C_{50}\right.$ values were $52.50 \mu \mathrm{g} \mathrm{m} \mathrm{I}^{-1}$ for HeLa vs. $47.64 \mu \mathrm{g} \mathrm{m} \mathrm{I}^{-1}$ for HeLa CK cells), whereas opposite results were obtained for cisplatin-resistant laryngeal carcinoma cells $\left(\mathrm{IC}_{50}\right.$ values were $51.98 \mu \mathrm{g} \mathrm{m} \mathrm{I} \mathrm{I}^{-1}$ for HEp-2 vs. $>60.00 \mu \mathrm{g} \mathrm{m} \mathrm{I}^{-1}$ for CK2 cells). Treatment with BV alone induced a necrotic type of cell death, as shown by characteristic morphological features, fast staining with ethidium-bromide and a lack of cleavage of apoptotic marker poly (ADP-ribose) polymerase (PARP) on Western blot. Combined treatment of BV and cisplatin induced an additive and/or weak synergistic effect towards tested cell lines, suggesting that BV could enhance the killing effect of selected cells when combined with cisplatin. Therefore, a greater anticancer effect could be triggered if BV was used in the course of chemotherapy. Our results suggest that combined treatment with BV could be useful from the point of minimizing the cisplatin concentration during chemotherapy, consequently reducing and/or postponing the development of cisplatin resistance.

Keywords: bee venom; melittin; cytotoxicity; tumour cells; drug resistance; cisplatin; apoptosis; necrosis

\section{Introduction}

Regardless of major scientific and technological advancements in combinatorial chemistry, drugs derived from natural products still make an enormous contribution to drug discovery today (Cragg and Newman, 2000; Gordaliza, 2007; da Rocha et al., 2001). A large number of studies in the past few years have reported on the anticancer ability of a wide spectra of natural products derived from plants and animals (Mehta and Pezzuto, 2002; Nobili et al., 2009), and the majority of those studies are especially interested in the effects of venoms from snakes, spiders, scorpions and in particular from honeybees (Heinen and da Veiga, 2011; Oršolić, 2012; Son et al., 2007) towards different types of tumour cell lines. Venom from Apis mellifera has been used for centuries in traditional medicine as a source of drugs to cure different ailments (Cherniack, 2010; Gajski and Garaj-Vrhovac, 2011; Garaj-Vrhovac and Gajski, 2009; Son et al., 2007).

Several beneficial roles of BV are also known today, such as radioprotective (Gajski and Garaj-Vrhovac, 2009), antimutagenic (Varanda et al., 1999), antinociceptive (Baek et al., 2006) and in recent times anticancer effects (Oršolić, 2012; Son et al., 2007). Recent reports indicate several mechanisms of BV cytotoxicity on different types of cancer cells such as cell cycle alterations, effects on proliferation and/or growth inhibition, as well as induction of apoptosis or necrosis (Gajski et al., 2011; Hu et al., 2006;
Ip et al., 2008a, b, 2012; Jang et al., 2003; Jo et al., 2012; Lee et al., 2007; Liu et al., 2002; Moon et al., 2006; Oršolić, 2009; Park et al., 2011). Therefore, BV has generated a great deal of interest as a possible therapeutic modality.

Venom itself is a very complex mixture of a variety of different active peptides: melittin (MEL), apamin, adolapin and mast cell degranulating (MCD) peptide (Habermann, 1972; Hider, 1988). In addition, it also contains enzymes, biologically active amines and non-peptide components including lipids, carbohydrates and free amino acids all with many cellular activities (Lariviere and Melzack, 1996). Two major components of BV are MEL and phospholipase $A_{2}\left(P L A_{2}\right.$ ) (Habermann, 1972; Stuhlmeier, 2007). MEL is a small protein containing 26 amino acids and it is the 
principal toxin in the BV, constituting around $50 \%$ of the whole BV according to the literature (Oršolić, 2012; Son et al., 2007). MEL has a broad range of actions towards different types of cells through its interactions with the plasma membrane and the enzyme system, and its lytic activity is probably caused by its ability to insert into phospholipids layers (Dempsey, 1990; Raghuraman and Chattopadhyay, 2007). PLA 2 , which makes around $10 \%$ of the whole BV, is a member of the group of enzymes that catalyze the hydrolysis of the sn-2 fatty acyl-ester bond of membrane glycero3-phospholipids resulting in diverse biological effects (Kwon et al., 2002; Six and Dennis, 2000; Valentin and Lambeau, 2000). Hydrolysis of these compounds generates lysophospholipids. Interestingly, lysolipids have therefore been proposed for anticancer therapies because of their antiproliferative effects and cytotoxicity (Ashagbley et al., 1996; Putz et al., 2006; Samadder et al., 2004).

The major obstacle for successful treatment of tumour patients with the standard chemotherapy is the development of drug resistance during the course of chemotherapy. Cisplatin is today one of the most widely used anticancer drugs for the treatment of a number of solid tumours (Boulikas and Vougiouka, 2003). It is generally accepted that cisplatin is a DNA damaging agent, because its cytotoxic effect is based upon the formation of platinum-DNA adducts. As the consequence of DNA platination, the cell cycle is arrested in order to allow the cell to repair the damage. If repair fails, apoptosis is induced by activation of various pathways (Fink \& Howell, 2000; Fuertes et al., 2003). However, recently it has been found that cisplatin can also induce non-DNA damage owing to formation of reactive oxygen species (ROS) (Brozović et al., 2010). The therapeutic outcome of cisplatin-based chemotherapy can be impaired by intrinsic or acquired resistance. Cisplatin resistance is the consequence of multifactor events. Several molecular mechanisms of resistance may occur in the same cell population. They include decreased accumulation and increased detoxification of cisplatin, more efficient removal of platinum-DNA adducts, an enhanced capacity to replicate past adducts, inhibition of apoptosis and a recently recognized mechanism, cell adhesion-mediated cisplatin resistance (Brozović et al., 2008, 2010; Köberle et al., 2010; Stewart, 2007; Zisowsky et al., 2007).

The aim of the present study was to investigate the possible combined anticancer ability of BV and cisplatin towards tumour cells in vitro. As the content of BV can be influenced by many factors, first we identified several peptides of BV in the BV sample used in the course of the study and determined the exact concentration of MEL. Next, we examined the cytotoxic effect of BV alone on parental cervical carcinoma HeLa cells and laryngeal carcinoma HEp-2 cells, as well as their cisplatin-resistant HeLa CK and CK2 sublines, respectively. Because sublethal concentrations of BV can stimulate cell growth, we used higher BV concentrations, all a bit lower than those which induce the killing of a large part of the treated cell population. According to our previous data the doses used were between 30 and $60 \mu \mathrm{g} \mathrm{ml}^{-1}$ of BV (Gajski et al., 2011). Additionally, we examined morphological changes and the type of cell death that was induced by BV. Finally, we investigated the combined treatment of cisplatin and BV on parental and cisplatin-resistant cells lines.

\section{Materials and Methods}

\section{Chemicals and Cell Media}

BV, MEL, 3-(4,5-dimethylthiazol-2-yl)-2,5-diphenyltetrazolium bromide (MTT), antibiotics (penicillin and streptomycin) and cisplatin (cDDP) were purchased from Sigma (St Louis, MO, USA); acridine-orange
(AO), Coomassie Brilliant Blue G-250 and ethidium-bromide (EtBr) were from Serva (Heidelberg, Germany); bovine serum albumin (BSA) and Dulbecco's modified Eagle's medium (DMEM) were from Gibco (Gaithersburg, MD, USA). All other chemicals not specifically cited here were purchased from Kemika (Zagreb, Croatia).

\section{Analysis of BV by Mass Spectrometry}

Mass spectrometry (MS) and tandem MS experiments were performed on a Bruker amaZon ETD ion trap system (Bruker Daltonik GmbH, Bremen, Germany) which incorporates a negative chemical ionization source capable of providing reagent anions for both electron transfer dissociation (ETD) and proton transfer reaction (PTR). Solutions of BV and MEL were prepared by dissolving dried samples in ethanol/water (50:50, 0.1\% formic acid). All samples were introduced into the electrospray ionization (ESI) source by direct infusion at a flow rate of $65 \mu \mathrm{h} \mathrm{h}^{-1}$. The temperature and flow rate of the drying gas were set at $210{ }^{\circ} \mathrm{C}$ and $51 \mathrm{~min}^{-1}$, respectively. ETD, PTR and collision induce dissociation (CID) conditions were optimized in order to maximize the dissociation and the appearance of the product ion spectra. All spectra were acquired in a positive mode using a scan range from 200 to $3000 \mathrm{~m} / \mathrm{z}$. DataAnalysis software 4.0 (Bruker Daltonik $\mathrm{GmbH}$ ) was used for analysis (charge deconvolution and data reduction) and extraction of the MS and tandem MS data. Peptide sequence assignment was done using BioTools 3.2 (Bruker Daltonik GmbH).

The concentration of MEL in the BV sample was determined by direct infusion ESI-MS, without chromatographic separation. A calibration curve was obtained by plotting the peak height of the MEL-extracted ion chromatogram (all available charge states) as a function of the concentration.

\section{Cell Cultures}

Human cervical carcinoma HeLa cells and their drug-resistant subline HeLa CK as well as human laryngeal carcinoma HEp-2 cells and their drug-resistant CK2 subline were used in the present study. Cisplatin-resistant HeLa CK cells were derived from the human cervical carcinoma HeLa cell line (Osmak and Eljuga, 1993), whereas cisplatin-resistant CK2 cells were derived from HEp-2 cells as described previously (Osmak, 1992; Osmak et al., 1993). All cell lines were maintained as a monolayer culture in DMEM (Gibco) supplemented with 10\% BSA (Gibco) and antibiotics (penicillin and streptomycin) in a humified atmosphere at $37{ }^{\circ} \mathrm{C}$ with $5 \% \mathrm{CO}_{2}$ and were sub-cultured every 3-4 days.

\section{Cell Treatment with BV}

Cells were seeded and after overnight incubation, they were treated with BV. Just before the beginning of the treatment, BV was dissolved in sterile redistilled water at $25^{\circ} \mathrm{C}$ as $1 \mathrm{mg} \mathrm{ml}^{-1}$ stock solution and then dissolved in growth medium to a broad range of concentrations. At a certain time point after the treatment, cells were collected for further experiments. Each experiment was repeated two or three times.

\section{Cytotoxicity Assay}

Cytotoxicity of the whole BV towards cervical HeLa and laryngeal Hep-2 carcinoma parental cells and their drug-resistant HeLa CK and CK2 sublines was determined by the modified colorimetric MTT assay (Mickisch et al., 1990). Additionally, we used the same test to evaluate the cell response to cisplatin treatment as well as 
to combined treatment with BV and cisplatin. MTT stains cells that have active mitochondria, i.e. live viable cells. Briefly, $2.5 \times 10^{3}$ cells were seeded into 96-well microtiter tissue culture plates. On the following day, the medium was aspirated and replaced with fresh growth medium in which appropriate concentrations of whole BV diluted in medium was added. Each concentration was tested in triplicate. The cells were continuously treated with BV for $72 \mathrm{~h}$ at $37^{\circ} \mathrm{C}$. For the combined treatment with BV and cisplatin, cells were pretreated with concentrations of BV for $1 \mathrm{~h}$ and then different concentrations of cisplatin were added to the cultures. After $72 \mathrm{~h}$ the medium was aspirated and $20 \mu \mathrm{g}$ of MTT dye per $0.04 \mathrm{ml}$ medium was added to each well. After $4 \mathrm{~h}$ of incubation at $37^{\circ} \mathrm{C}$, formazan crystals were dissolved in dimethyl sulfoxide (DMSO; $0.17 \mathrm{ml}$ per well), the plates were mechanically agitated for 5 min and the absorbance at $545 \mathrm{~nm}$ was determined on a microtiter plate reader (Awareness Technology Inc., Palm City, FL, USA).

\section{Morphological Changes and the Type of Cell Death}

Next, $2.5 \times 10^{3}$ cells per well of cervical carcinoma HeLa cells or their drug-resistant subline HeLa CK cells were plated in tissue culture plates. Cells were then incubated with the whole BV at different concentrations for $1 \mathrm{~h}$. As a positive control cells were treated for $24 \mathrm{~h}$ with $20 \mu \mathrm{M}$ cisplatin which is known to induce apoptotic cell death (Eastman, 1990). The type of cell death was determined by staining cells with DNA-intercalators AO and $\mathrm{EtBr}$, which give green fluorescence of the nuclei in live cells and red fluorescence of the nuclei in dead cells, respectively. In brief, adherent and floating cells were collected by centrifugation and resuspended in a small volume of culture medium, after which in $10 \mu \mathrm{l}$ of cell suspension, $2 \mu \mathrm{l}$ of $A O\left[15 \mu \mathrm{g} \mathrm{ml}^{-1}\right.$ in phosphate-buffered saline (PBS)] and $2 \mu \mathrm{l}$ of $\mathrm{EtBr}\left(50 \mu \mathrm{g} \mathrm{ml}^{-1}\right.$ in PBS) were added. Samples were viewed under the epifluorescence microscope Axiovert 35 (Opton, Germany). Fluorescence was detected through the BP 450-490, FT 510, LP 520 filter. Images were taken with the camera Pixera Pro150ES (San Jose, CA, USA).

\section{Western Blot Analysis}

Next, $4 \times 10^{5}$ cells were seeded and on the next day treated with the whole BV in different concentrations. As a positive control, cells were treated for $24 \mathrm{~h}$ with $20 \mu \mathrm{M}$ cisplatin which is known to induce apoptotic cell death (Eastman, 1990). Total cellular extracts were obtained by lysing the cells in lysis buffer $(25 \mathrm{mM}$ HEPES, pH 7.5, $150 \mathrm{mM} \mathrm{NaCl}, 1 \%$ Triton X-100, $10 \mathrm{mM} \mathrm{MgCl}$, $1 \mathrm{mM}$ EDTA, 2\% glycerol, $1 \mathrm{mM}$ PMSF) on ice. The protein concentration was determined by Bradford (1976) and equal amounts of protein were separated by SDS-PAGE (12.5\%) and blotted onto nitrocellulose membrane (Schleicher \& Schüll, Dassel, Germany). After overnight incubation at $4{ }^{\circ} \mathrm{C}$ in blocking buffer $[5 \%$ milk $(\mathrm{w} / \mathrm{v})$ in TBS buffer with $0.1 \%$ Tween $20(\mathrm{v} / \mathrm{v})]$, the membranes were probed with monoclonal antibody against poly(ADP-ribose) polymerase (PARP; Pharmingen, San Diego, CA, USA). Primary antibodies were detected with corresponding horseradish-peroxidase conjugated secondary antibodies (GE Healthcare, Piscataway, NJ, USA), followed by Western Blot Chemiluminescence Reagent Plus detection according to the protocol provided by the manufacturer (PerkinElmer Life Science, Boston, MA, USA). As an internal protein loading control, ERK2 protein expression was determined by reprobing the membranes with ERK2 specific rabbit polyclonal antibody (Santa Cruz Biotechnology, Santa Cruz, CA, USA).

\section{Statistical Analysis}

The isobologram analysis method was used to determine the extent of synergism on combining two agents for their possible therapeutic effect. The synergy index $(q)$ was calculated according to the formula $q=\mathrm{E}(\mathrm{A}+\mathrm{B}) /(\mathrm{EA}+\mathrm{EB}-\mathrm{EA} \times \mathrm{EB})(\mathrm{Jin}, 1980)$. This method was used to elucidate the possible additive and/or synergistic effect of $B V$ and cisplatin. $E(A+B)$ represent the inhibition rate of the combination group, and EA and EB represent the individual group. If the value of $q$ ranges from 0.85 to 1.15 , the role of combination is just the simple addictive effect. While from 1.15 to 2.0, the role of combination will be a synergistic effect. Greater than 2.0, it represents that there is a significant synergistic effect between the two agents. Statistical differences between the mean values were calculated using Student's $t$-test. Differences were considered significant when $P<0.05$.

\section{Results}

\section{Analysis of BV Content}

MS and tandem MS experiments were performed in order to examine the content of BV and to determine the exact concentration of MEL in BV that was used in the present study. Peptides MEL, apamin, MCD peptide and tertiapin were identified by tandem MS as components of BV. Charge deconvoluted low-energy CID/ETD spectra are shown on Fig. 1. Identified peptides are in agreement with previous findings regarding peptide components of BV (Oršolić, 2012; Son et al., 2007). Additionally, the concentration of MEL in BV was determined (Fig. 2). MEL mass fraction in the BV sample was estimated at 0.19.

\section{Cytotoxicity of BV in vitro}

A cytotoxic effect of whole BV was evaluated on human cervical carcinoma HeLa cells and human laryngeal carcinoma HEp-2 cells and their drug-resistant HeLa CK and CK2 sublines, respectively. The results of the MTT assay are presented in Fig. 3. BV was cytotoxic for all examined cell lines, and the toxicity was dose dependent. The cytotoxicity was also cell type dependent. Although parental HeLa and HEp- 2 cells exhibited almost the same sensitivity with $\mathrm{IC}_{50}$ values of 52.50 and $51.98 \mu \mathrm{g} \mathrm{ml}^{-1}$, respectively, we observed a different pattern in the sensitivity of their drug-resistant sublines. HeLa CK cells were more sensitive towards BV than the parental cells with the $\mathrm{IC}_{50}$ value of $47.64 \mu \mathrm{g} \mathrm{ml}^{-1}$, compared with CK2 cells that displayed the highest resistance towards BV with a $\mathrm{IC}_{50}$ above $60.00 \mu \mathrm{g} \mathrm{ml}^{-1}$.

\section{BV-Induced Morphological Changes and the Type of Cell Death}

Light and fluorescent microscopy was used for the determination of morphological changes induced in the pair of cervical carcinoma cells: parental HeLa cells and their cisplatin-resistant HeLa CK subline. On both cell lines we saw similar morphological alterations that were induced rapidly after the addition of whole BV: rounded and granulated cells, shrinkage, and separation from neighbouring cells and eventual detachment from the culture plates (Fig. 4). Very few such features were observed in the control cells. One hour after the treatment we also determined the type of cell death using fluorescent microscopy. As shown in Fig. 4, BV induced a necrotic type of cell death in both HeLa and HeLa CK cells as opposed to treatment with cisplatin where apoptosis was observed. Detection of cells dying by a necrotic 

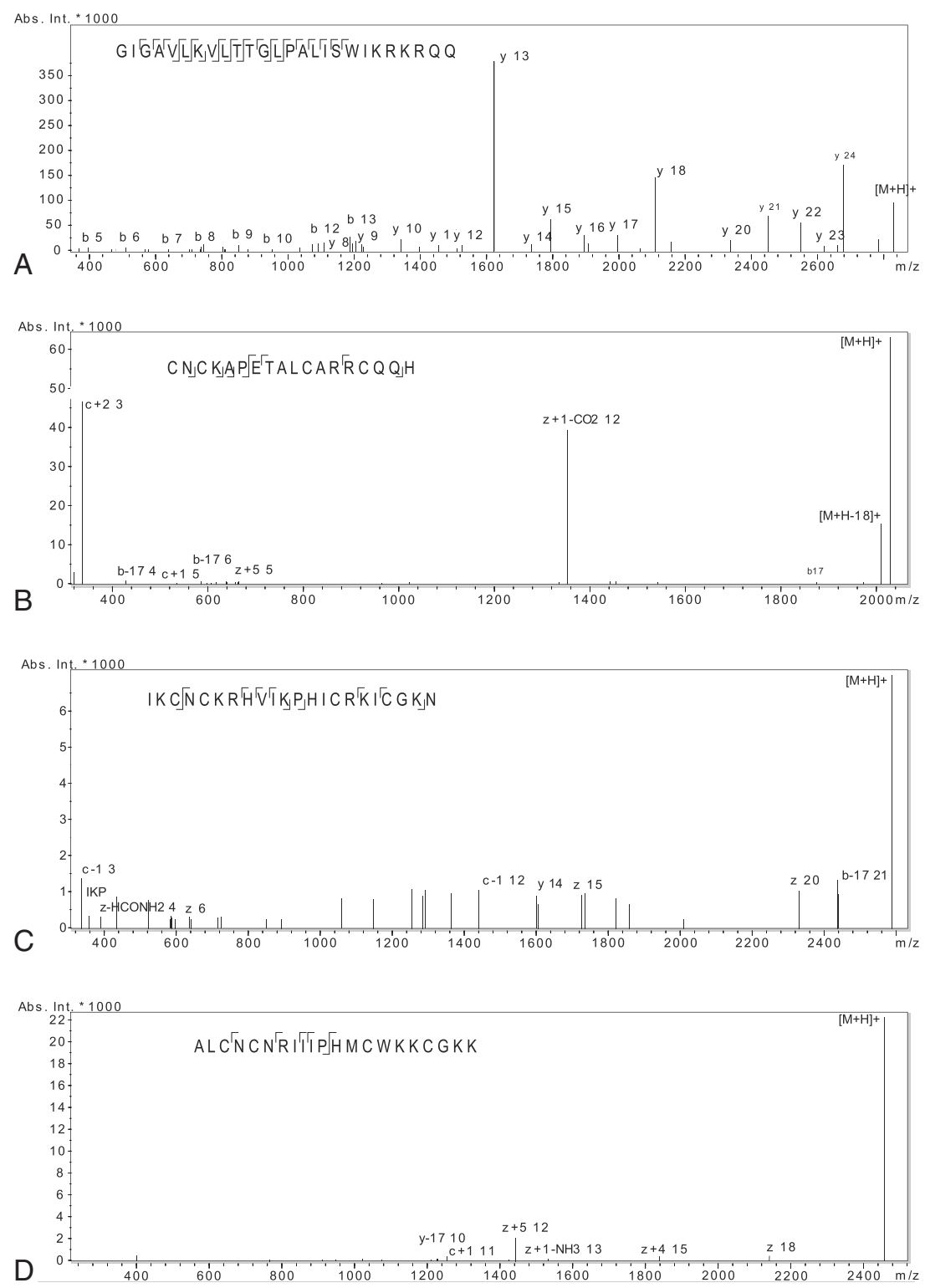

Figure 1. Charge deconvoluted low-energy collision induce dissociation/electron transfer dissociation (CID/ETD) spectrum of (A) melittin (GIGAVLKVLTTGLPALISWIKRKRQQ), (B) apamin (CNCKAPETALCARRCQQH - amidated C-terminus, crosslink SS 1-11 and SS 3-15), (C) mast cell degranulating peptide (IKCNCKRHVIKPHICRKICGKN - amidated C-terminus, crosslink SS 3-15 and SS 5-19) and (D) tertiapin (ALCNCNRIIIPHMCWKKCGKK - amidated C-terminus, crosslink SS 3-14 and SS 5-18).

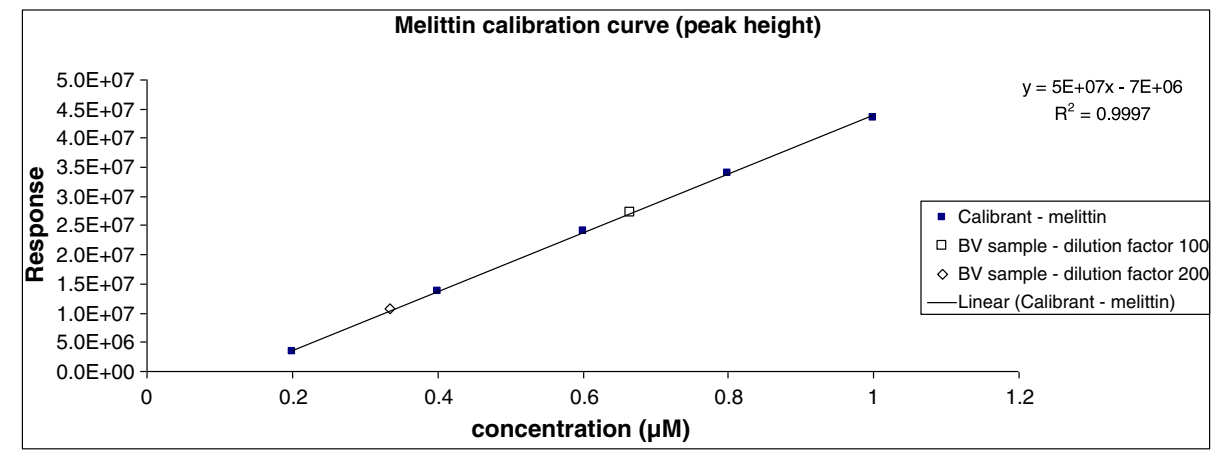

Figure 2. Melittin (MEL) calibration curve obtained by direct infusion electrospray ionization-mass spectrometry (ESI-MS) assay. 

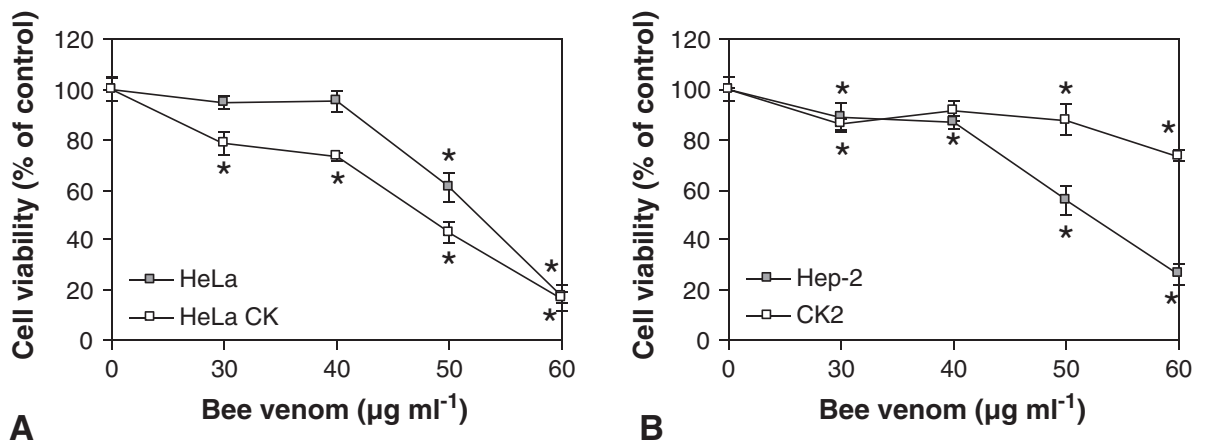

Figure 3. Cytotoxic effect of bee venom (BV) on human cervical carcinoma HeLa cells (A) and human laryngeal carcinoma HEp-2 cells (B) and their drug-resistant HeLa CK and CK2 sublines, respectively. Cells were seeded in 96-well tissue culture plates and $24 \mathrm{~h}$ later BV was added. Cells were incubated for $72 \mathrm{~h}$ with indicated concentrations of BV and percentage of cell viability was calculated in relation to the untreated control. The viability was determined with the modified colorimetric MTT assay. *Statistically significant compared with the corresponding control $(P<0.05)$.

A

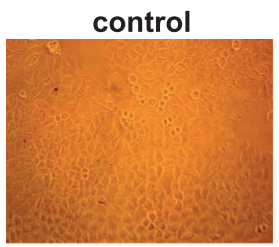

HeLa

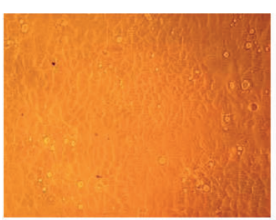

B

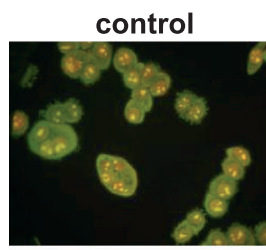

HeLa

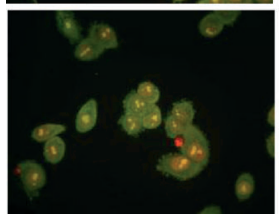

CDDP
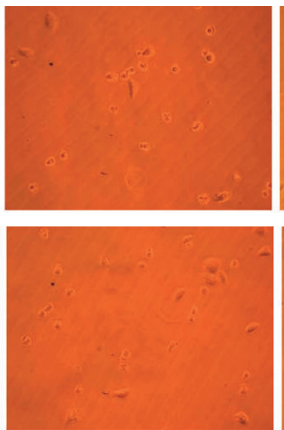

CDDP
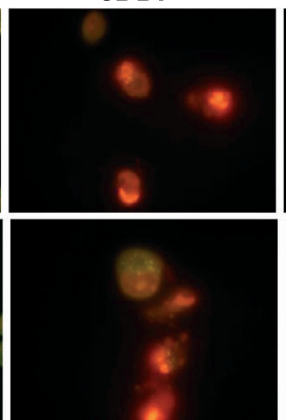

$50 \mu \mathrm{g} \mathrm{ml}^{-1}$
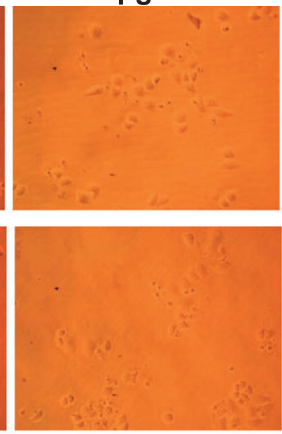

$50 \mu \mathrm{g} \mathrm{ml}^{-1}$

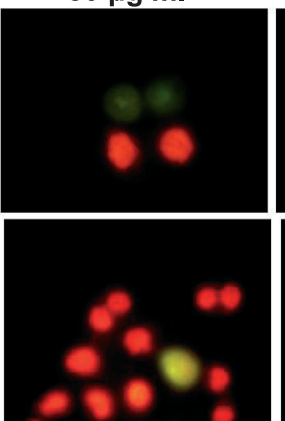

$60 \mu \mathrm{g} \mathrm{ml}^{-1}$
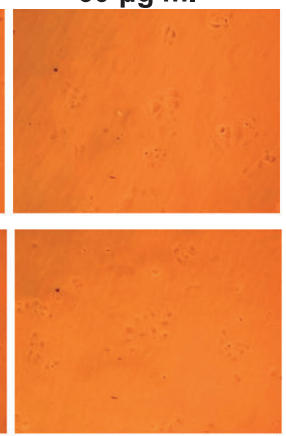

$60 \mu \mathrm{g} \mathrm{ml}^{-1}$

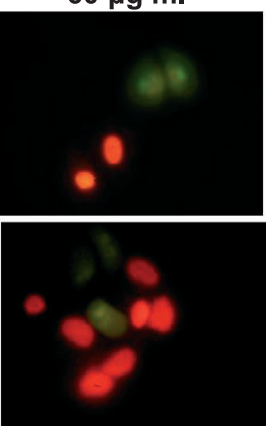

Figure 4. Microphotographs of human cervical carcinoma HeLa cells and their drug-resistant HeLa CK subline after bee venom (BV) treatment ( $\mu \mathrm{g} \mathrm{ml}^{-1}$ ). Cells were incubated for $1 \mathrm{~h}$ with indicated concentrations of BV and viewed and photographed under the light microscope to determined morphological changes induced by the treatment with the whole BV. Pictures were taken at magnification $400 \times(A)$. For determination of apoptotic and/or necrotic nuclear morphology cells were also incubated for $1 \mathrm{~h}$ with indicated concentrations of BV, stained with DNA-intercalators acridine-orange (AO) and ethidiumbromide (EtBr), and viewed and photographed under the epifluorescent microscope. Pictures were taken at magnification 1000× (B). As a positive control cells were treated for $24 \mathrm{~h}$ with cisplatin (CDDP, $20 \mu \mathrm{M})$ which is known to induce apoptotic cell death.

type of cell death employs the fact that, in contrast to apoptosis, the cell membrane becomes permeable very early, but the nucleus disintegrates late. So, pyknotic and fragmented nuclei are characteristic for apoptosis, but round and intact nuclei indicate a necrotic type of cell death. It is important to note that cells in the late stages of apoptosis are also membrane permeable owing to secondary necrosis.

\section{Induction of PARP Cleavage by BV}

Using morphological alteration and staining with fluorescent dyes, we show in this study that BV induces necrosis in both
HeLa and HeLa CK cells. However, to confirm this observation, we additionally explored whether BV can induce apoptosis. For this purpose we used HeLa cells and examined whether treatment with BV induces cleavage of PARP, which is a regulatory molecule whose cleavage is known to indicate apoptotic cell death (Kaufmann et al., 1993). As expected, Western blot analysis did not show any cleavage of PARP as shown in Fig. 5.

\section{Effect of Combined Treatment with BV and Cisplatin}

To test the impact of the combined treatment of BV and cisplatin, human cervical carcinoma HeLa cells and human laryngeal 
carcinoma HEp-2 cells, as well as their cisplatin-resistant HeLa CK and CK2 sublines, were pre-treated with BV in different concentrations for $1 \mathrm{~h}$, after which cisplatin was added. Cytotoxicity of such a combined treatment against human cervical carcinoma HeLa cells and their cisplatin-resistant HeLa CK subline is shown in Fig. 6, whereas cytotoxicity on human laryngeal carcinoma HEp-2 cells and their cisplatin-resistant CK2 subline was shown in Fig. 7. When combined treatment with cisplatin and BV was given to HeLa cells,

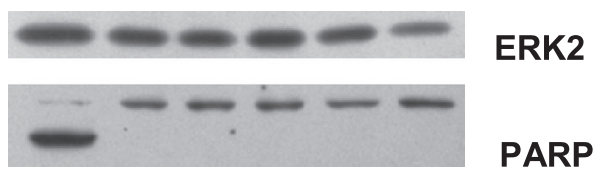

\section{$\begin{array}{lllllll}\text { cDDP } & 0 & 10 & 20 & 40 & 50 & \text { Bee venom }\left(\mu \mathrm{g} \mathrm{ml}^{-1}\right)\end{array}$}

Figure 5. Determination of cell death after bee venom (BV) treatment. Human cervical carcinoma HeLa cells were incubated for $1 \mathrm{~h}$ with indicated concentrations of BV. As a positive control cells were also treated with cisplatin (cDDP, $20 \mu \mathrm{M}$ ) for $24 \mathrm{~h}$ which is known to induce apoptotic cell death. The induction of apoptosis was determined by the cleavage of characteristic apoptotic protein poly (ADP-ribose) polymerase (PARP) by Western blot analysis. As an internal protein loading control, ERK2 protein expression was determined by re-probing the membranes with ERK2-specific antibody. A representative of three independent experiments is shown. cell sensitization was observed for a higher dose of cisplatin, and the highest dose of BV and a higher dose of cisplatin. In contrast, all three given doses of BV sensitized HeLa CK cells to both doses of cisplatin (Fig. 6). The combination of BV and cisplatin was again less cytotoxic to parental laryngeal carcinoma cells, while all three selected doses of BV increased the cell sensitivity of CK2 cells to both doses of cisplatin (Fig. 7). Thus, according to statistical analysis, both cisplatin-resistant sublines, HeLa CK and CK2 cells were more sensitive to cisplatin when pre-treated with BV compared with parental cells. The isobologram analysis method showed that the effect of BV and cisplatin, given in combination, on HeLa and HeLa CK cells was synergistic ( $q$ ranges from 1.15 to 2.0 ) for all the BV and cisplatin concentrations, although a significant synergistic effect was not observed. In contrast, the synergistic effect on HEp-2 cells was observed only for the highest BV concentration and for both cisplatin doses, whereas on CK2 cells only $40 \mu \mathrm{g} \mathrm{ml}^{-1}$ BV and both cisplatin doses showed a synergistic effect. It has to be pointed out that the synergistic effect was again non-significant since $q$ was lower than 2.0. All the other BV and cisplatin concentrations on HEp-2 and CK2 cells only gave an additive effect.

\section{Discussion}

Today there is increasing interest in anticancer treatment strategies involving natural products such as BV and strategies that combine standard chemotherapy with novel agents that could target cancer

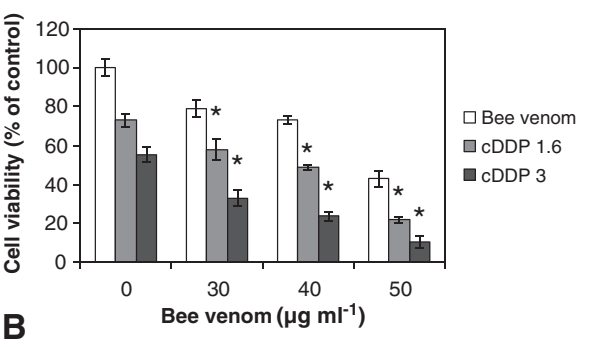

Figure 6. Sensitivity of human cervical carcinoma HeLa cells (A) and their drug-resistant HeLa CK cell subline (B) towards joint treatment with bee venom (BV) and cisplatin (CDDP). Cells were seeded in 96-well tissue culture plates and $24 \mathrm{~h}$ later BV was added. Cells were pre-treated for $1 \mathrm{~h}$ with indicated concentrations of BV $\left(\mu \mathrm{g} \mathrm{ml}^{-1}\right)$ after treatment with indicated concentrations of $\mathrm{CDDP}(\mu \mathrm{M})$ and percentage of cell viability was calculated in relation to untreated control. The viability was determined with the modified colorimetric MTT assay after $72 \mathrm{~h}$ of treatment. White columns represent cell viability obtained with BV treatment (from 0 to $50 \mu \mathrm{g} \mathrm{ml}^{-1}$ ), light-gray and dark-gray columns (under $0 \mu \mathrm{g} \mathrm{ml} l^{-1} \mathrm{BV}$ ) represents viability obtained with indicated CDDP doses, whereas light-gray and dark-gray columns (under 30,40 or $50 \mu \mathrm{g} \mathrm{ml}^{-1} \mathrm{BV}$ ) represent cell viability obtained by combined treatment with $\mathrm{BV}$ and cisplatin. * Statistically significant compared with the corresponding $\mathrm{CDDP}$ treatment $(P<0.05)$.
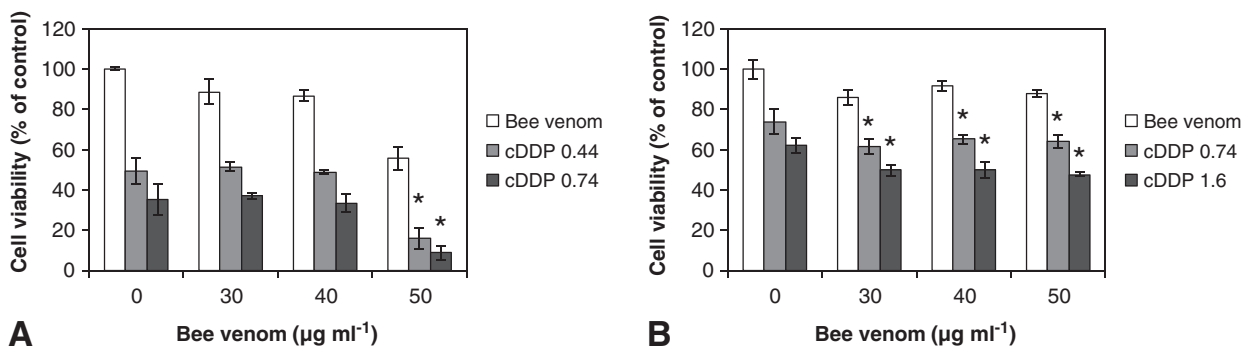

Figure 7. Sensitivity of human laryngeal carcinoma HEp-2 cells (A) and their drug-resistant CK2 cell subline (B) towards joint treatment with bee venom (BV) and cisplatin (CDDP). Cells were seeded in 96-well tissue culture plates and $24 \mathrm{~h}$ later BV was added. Cells were pre-treated for $1 \mathrm{~h}$ with indicated concentrations of BV $\left(\mu \mathrm{g} \mathrm{ml}^{-1}\right)$ after treatment with indicated concentrations of $\operatorname{CDDP}(\mu \mathrm{M})$ and percentage of cell viability was calculated in relation to untreated control. The viability was determined with the modified colorimetric MTT assay after $72 \mathrm{~h}$ of treatment. White columns represent cell viability obtained with BV treatment (from 0 to $50 \mu \mathrm{g} \mathrm{ml}^{-1}$ ), light-gray and dark-gray columns (under $0 \mu \mathrm{g} \mathrm{ml} l^{-1} \mathrm{BV}$ ) represent viability obtained with indicated CDDP doses, while light-gray and dark-gray columns (under 30,40 or $50 \mu \mathrm{g} \mathrm{ml}^{-1} \mathrm{BV}$ ) represent cell viability obtained by combined treatment with BV and cisplatin. *Statistically significant compared with the corresponding CDDP treatment $(P<0.05)$. 
cells. New therapeutic approaches have attempted to use chemotherapeutic agents derived from venoms of animals and the most frequently used in recent years is venom derived from $A$. mellifera (Gajski et al., 2012; Gajski and Garaj-Vrhovac, 2013; Oršolić, 2012; Son et al., 2007).

$\mathrm{BV}$ is a complex mixture of different active compounds and its toxic effects could be largely attributed to its small protein MEL that comprises around $19 \%$ of dry BV in our sample. PLA $A_{2}$ whose activity is enhanced by MEL, as well as other peptide components such as apamin, MCD peptide and/or tertiapin, was identified in the present study as well. Those are the components with known cytotoxic effects towards a variety of cells and are likely to be responsible for the effects encountered in our study.

It has also been demonstrated that BV inhibits the growth of several types of cancer cell lines (Hu et al., 2006; Ip et al., 2008a, b, 2012; Jang et al., 2003; Jo et al., 2012; Lee et al., 2007; Moon et al., 2006; Park et al., 2011). Previously, we reported that BV is cytotoxic against different types of tumour and nontumour cell lines in vitro (Gajski et al., 2011). Those results showed a decreased viability after BV treatment that was more prominent in tumour than in non-tumour cells suggesting that BV preferentially kills tumour cells. In addition to evaluating the cytotoxic effect of BV alone, and the morphological changes and the type of cell death induced after BV treatment, the present study aimed to investigate the possible combined anticancer ability of BV and cisplatin towards tumour cells in vitro in a narrower concentration range around $I C_{50}$ values. This was done using two different cultured human cell lines: human cervical carcinoma HeLa and laryngeal carcinoma HEp-2 cells and their cisplatin-resistant sublines HeLa CK and CK2 cells, respectively.

As the properties of carcinogenic agents are growth-inhibition power and the ability to induce cell death, these properties are widely used in anticancer therapies. In the present study, we examined the cytotoxic effect of the whole BV and its impact on cisplatin cytotoxicity on two tumour cells lines and their sublines resistant to cisplatin. Using the spectrophotometric MTT assay, we first determined cell viability after treatment, whereas using light and fluorescent microscopy, in addition to Western blot analysis, we described morphological changes and the type of cell death induced. Our results showed that BV was cytotoxic to all tested cell types and that cytotoxicity was dose- and celltype dependent. Parental HeLa and HEp-2 cells exhibited almost the same sensitivity towards BV treatment. In contrast, in their drug-resistant sublines we observed a different pattern of sensitivity. HeLa CK cells were more sensitive towards BV than the parental cells, whereas CK2 cells displayed resistance towards BV. Such differences may be as a result of the biological and genetic variations among the investigated cell types.

The cytotoxic effect of BV could be based on the effect of MEL. Specifically, this compound shares its amphipatic properties with a series of peptides that are characterized by their capacity to disturb cell membrane bilayer integrity, either by creation of defects, disruption, or through pore formation. The resulting opening in the lipid bilayer leads to the collapse of transmembrane electrochemical gradients (Bechinger and Lohner, 2006). In contrast to the normal cells with low membrane potential, the cell membranes of tumour cells maintain a large membrane potential. Therefore, many lytic peptides together with MEL selectively disrupt the tumour cell membranes rather than those of normal cells, and that could be the important mechanism of the anticancer activity of BV (Holle et al., 2003; Moon et al., 2006; Son et al., 2007).
The collapse of the membrane integrity was confirmed in our system by the staining of treated cells with $\mathrm{EtBr}$, a dye that only enters the cells with a damaged cell membrane. In all cell lines tested we observed similar morphological alterations induced by BV. These changes occurred rapidly after cell treatment. Cell rounding and granulation, as well as detachment from the substratum, along with the staining with fluorescent dye $\mathrm{EtBr}$ suggests the cell membrane damage as the cause of cell death, and the necrosis as the most probable type of the cell death in the given concentrations. In the literature there are contradictory data about the type of cell death which could be induced by BV. BV caused apoptosis in lung carcinoma cells, hepatoma cells, leukemic cells, breast cancer cells, cervical epidermoid carcinoma cells, synovial fibroblasts, prostate cancer cells, bladder cancer cells and melanoma cells (Hong et al., 2005; Hu et al., 2006; Ip et al., 2008a, b, 2012; Jang et al., 2003; Moon et al., 2006; Park et al., 2011; Tu et al., 2008). Recently reported results demonstrate that in fibroblast-like synoviocytes, in addition to apoptotic-like cell death induced by BV, necrotic cell death was present as well whereas in human mammary carcinoma cells, cervical carcinoma cells and Chinese hamster lung fibroblasts both apoptotic and necrotic activities were encountered (Oršolić, 2009; Oršolić et al., 2003; Stuhlmeier, 2007). In addition, Lee et al. (2007) in their study on human lymphoma cells did not observe sub-G1 fractions or cleavage of caspase-9, -3 or PARP suggesting that BV induced cell death but these cellular events were not accompanied by the activation of the apoptotic machinery.

In the present study, the effects of BV were related to necrosis, which was confirmed by fluorescent microscopy and Western blot analysis. Although decades of research clarified the pathways that regulate apoptosis and allowed the development of novel diagnostic and therapeutic modalities in cancer treatment, only recently has the significance of necrosis become the focus of investigations (Amaravadi and Thompson, 2007). Necrosis is an irreversible inflammatory form of cell death with a possible implication for cancer therapy. Necrotic cell death is often referred to as unscheduled cell death, suggesting that within a multicellular organism it is an unregulated process. The disruption of the plasma membrane that is characteristic of necrotic cell death leads to the spillage of intracellular proteins that activates a damage response from the host immune system (Amaravadi and Thompson, 2007; Zeh and Lotze, 2005). This rapid inflammatory response and immune amplification of the damage signal is in contrast to apoptotic cells that are silently removed by tissue macrophages. Thus, necrosis was viewed as strictly a pathologic form of cell death that is not a physiologically programmed process. However, a large number of experimental data indicate that, much like apoptosis, specific genes have evolved to regulate necrotic cell death, suggesting that necrosis may be a well-regulated process activated by rather specific physiological and pathological stimuli (Amaravadi and Thompson, 2007; Festjens et al., 2006; Golstein and Kroemer, 2007; Proskuryakov and Gabai, 2010). Hence, necrosis is not to be excluded as a possible way of cancer cell death.

Most of the anticancer agents, including cisplatin, can induce drug resistance. In order to interact with intracellular targets, they need to penetrate through membranes. Once they have reached the cytosol many of them are deactivated and than transported out of the cell before interacting with intracellular targets (Köberle et al., 2010; Pérez-Tomás, 2006; Schweizer, 2009; Stewart, 2007). In order to battle such resistance and to 
reduce normal cell cytotoxicity, the development of novel drugs and delivery systems with novel mode of actions and high cancer cell selectivity are crucial. In the search for new cancer agents and delivery systems, cationic amphiphilic peptides such as MEL have recently attracted attention owing to their novel mode of actions and decreased possibility of resistance development (Hoskin and Ramamoorthy, 2008; Leuschner and Hansel, 2004; Papo and Shai, 2005; Schweizer, 2009).

In our study, pre-treatment with BV enhanced cytotoxicity of cisplatin in all cell lines. We used the isobologram analysis method to determine the extent of synergism when combining BV and cisplatin. The synergy index $(q)$ on HeLa and HeLa CK cell lines, for all the concentrations tested, indicated that a combination of BV and cisplatin could be synergistic although the synergistic effect was not significant. As for the HEp-2 and CK2 cells, the same was observed only for certain BV and cisplatin concentrations, whereas other BV and cisplatin concentrations gave only an additive effect. Nevertheless, not only is there a direct effect of BV on the growth of tested tumour cells, but combined BV and cisplatin treatment showed enhanced cytotoxicity which could be useful from the point of minimizing the cisplatin concentration during chemotherapy. The possible mechanism of action could be a creation of defects, disruption and pore formation in the cell membrane bilayer by MEL, enhancing cisplatin uptake and accumulation and thus causing synergistic i.e. enhanced cytotoxic effect of cisplatin. The effects of BV and MEL on cytotoxicity of different cytostatic drugs was previously noticed in leukemic L1210 cells (Lazo et al., 1985), HeLa cells, Chinese hamster lung fibroblasts V79 cells (Oršolić, 2009) and human ovarian cancer A2780cp cells (Alizadehnohi et al., 2012). Oršolić (2009) investigated the cytotoxic effects of BV applied alone or in combination with the DNA damaging drug bleomycin on HeLa and V79 cells. Bleomycin caused a dose-dependent decrease in cell survival, and when used with a non-lethal dose of BV, its lethal effect was potentiated. Oršolić (2009) concluded that BV, by preventing the repair of damaged DNA, increases bleomycin lethality and inhibits recovery from the bleomycin-induced damage. Moreover, Alizadehnohi et al. (2012) showed that lethal effects of cisplatin are potentiated by the addition of a non-lethal dose of BV. As DNA is the main target of cisplatin, it is very likely that BV is able to potentiate the lethal effect of cisplatin in this way. Although the detailed mechanism for the action of BV and cisplatin needs further clarification, the inhibitory effect on tumour cell lines is apparent. Because cisplatin cytotoxicity was enhanced with another drug, in this particulate case with BV, combination therapy may help overcome the challenge of tumour resistance towards standard chemotherapy.

In conclusion, BV is a mixture of different active compounds and its toxic effects could be largely attributed to its small protein MEL that comprises around 19\% of dry venom in our sample, PLA 2 which activity is enhanced by MEL, in addition to other peptide components such as apamin, MCD peptide and/ or tertiapin that were identified in the course of our study. BV, given in the range of 30 to $60 \mu \mathrm{g} \mathrm{ml}^{-1}$, was cytotoxic to parental cervical HeLa and laryngeal HEp-2 carcinoma cells. Their cisplatinresistant sublines exhibited an opposite pattern of sensitivity: HeLa CK cells were more sensitive to BV than their parental HeLa cells, whereas CK2 cells were resistant compared with HEp-2 cells. BV given alone induced very fast necrosis. The combined treatment of BV and cisplatin induced an additive and/or weak synergistic effect towards all the tested cell lines, suggesting that BV could enhance the killing effect of selected cells when combined with cisplatin, therefore, a greater anticancer effect could be triggered if BV was used in the course of chemotherapy. Minimizing the cisplatin concentration during chemotherapy by the addition of compounds that increase their cytotoxicity could be very useful for the patients, and also from the point of reducing and/or postponing the development of cisplatin resistance. Activities displayed by $\mathrm{BV}$ alone and by its combination with cisplatin could merit clinical investigation as a new agent in the treatment of cancer. In view of accumulating evidence on anti-proliferative and pro-cell death activity, BV could be used in the development of antitumor drugs. Nevertheless, more studies are required to show the suitability and safety of these types of drugs in anticancer therapies.

\section{Acknowledgement}

This work was supported by funds of the Ministry of Science, Education and Sport of the Republic of Croatia (grant nos. 022-0222148-2125, 098-0982913-2748 and 098-0982915-2945).

\section{Conflict of Interest}

The Authors did not report any conflict of interest.

\section{References}

Alizadehnohi M, Nabiuni M, Nazari Z, Safaeinejad Z, Irian S. 2012. The synergistic cytotoxic effect of cisplatin and honey bee venom on human ovarian cancer cell line A2780cp. J. Venom Res. 3: 22-27.

Amaravadi RK, Thompson CB. 2007. The roles of therapy-induced autophagy and necrosis in cancer treatment. Clin. Cancer Res. 13: 7271-7279. DOI: 10.1158/1078-0432.CCR-07-1595.

Ashagbley A, Samadder P, Bittman R, Erukulla RK, Byun HS, Arthur G. 1996. Synthesis of ether-linked analogues of lysophosphatidate and their effect on the proliferation of human epithelial cancer cells in vitro. Anticancer Res 16: 1813-1818.

Baek YH, Huh JE, Lee JD, Choi do Y, Park DS. 2006. Antinociceptive effect and the mechanism of bee venom acupuncture (Apipuncture) on inflammatory pain in the rat model of collagen-induced arthritis: Mediation by alpha2-Adrenoceptors. Brain Res. 1073-1074: 305-310. DOI: 10.1016/j.brainres.2005.12.086.

Bechinger B, Lohner K. 2006. Detergent-like actions of linear amphipathic cationic antimicrobial peptides. Biochim. Biophys. Acta 1758: 1529-1539. DOI: 10.1016/j.bbamem.2006.07.001.

Boulikas T, Vougiouka M. 2003. Cisplatin and platinum drugs at the molecular level. (Review). Oncol. Rep. 10: 1663-1682.

Bradford MM. 1976. A rapid and sensitive method for the quantitation of microgram quantities of protein of protein utilizing the principle of protein-dye binding. Anal. Biochem. 72: 248-254.

Brozović A, Majhen D, Roje V, Mikac N, Jakopec S, Fritz G, Osmak M, Ambriović Ristov A. 2008. $\alpha_{v} \beta_{3}$ integrin mediated drug resistance in human laryngeal carcinoma cells is caused by glutathione dependent elimination of drug induced reactive oxidative species. Mol. Pharmacol. 74: 1-9. DOI: 10.1124/mol.107.043836.

Brozović A, Ambriović-Ristov A, Osmak M. 2010. The relationship between cisplatin-induced reactive oxygen species, glutathione, and BCL-2 and resistance to cisplatin. Crit. Rev. Toxicol. 40: 347-359. DOI: $10.3109 / 10408441003601836$.

Cherniack EP. 2010. Bugs as drugs, Part 1: Insects: the "new" alternative medicine for the 21st century? Altern. Med. Rev. 15: 124-135.

Cragg GM, Newman DJ. 2000. Antineoplastic agents from natural sources: achievements and future directions. Expert Opin. Investig. Drugs 9: 2783-2797. DOI: 10.1517/13543784.9.12.2783.

da Rocha AB, Lopes RM, Schwartsmann G. 2001. Natural products in anticancer therapy. Curr. Opin. Pharmacol. 1: 364-369. DOI: 10.1016/ S1471-4892(01)00063-7.

Dempsey CE. 1990. The actions of melittin on membranes. Biochim. Biophys. Acta 1031: 143-161. DOI: 10.1016/0304-4157(90)90006-X.

Eastman A. 1990. Activation of programmed cell death by anticancer agents: cisplatin as a model system. Cancer Cells 2: 275-280. 
Festjens N, Vanden Berghe T, Vandenabeele P. 2006. Necrosis, a wellorchestrated form of cell demise: signalling cascades, important mediators and concomitant immune response. Biochim. Biophys. Acta 1757: 1371-1387. DOI: 10.1016/j.bbabio.2006.06.014.

Fink D, Howell SB. 2000. How does cisplatin kill cells? In Platinum-based Drugs in Cancer Therapy 7, Kelland LR, Farrell N (eds). Humana Press Inc.: Totowa, New Jersey, 149-167.

Fuertes MA, Alonso C, Perez JM. 2003. Biochemical modulation of cisplatin mechanisms of action: enhancement of antitumor activity and circumvention of drug resistance. Chem. Rev. 103: 645-662. DOI: $10.1021 / \mathrm{cr} 020010 \mathrm{~d}$.

Gajski G, Garaj-Vrhovac V. 2009. Radioprotective effects of honeybee venom (Apis mellifera) against $915-\mathrm{MHz}$ microwave radiationinduced DNA damage in Wistar rat lymphocytes: In vitro study. Int. J. Toxicol. 28: 88-98. DOI: 10.1177/1091581809335051.

Gajski G, Garaj-Vrhovac V. 2011. Bee venom induced cytogenetic damage and decreased cell viability in human white blood cells after treatment in vitro: a multi-biomarker approach. Environ. Toxicol. Pharmacol. 32: 201-211. DOI: 10.1016/j.etap.2011.05.004.

Gajski G, Čimbora-Zovko T, Osmak M, Garaj-Vrhovac V. 2011. Bee venom and melittin are cytotoxic against different types of tumor and nontumor cell lines in vitro. Cancer Res. J. 4: 159-174.

Gajski G, Domijan AM, Garaj-Vrhovac V. 2012. Alterations of GSH and MDA levels and their association with bee venom-induced DNA damage in human peripheral blood leukocytes. Environ. Mol. Mutagen. 53: 469-477. DOI: 10.1002/em.21708.

Gajski G, Garaj-Vrhovac V. 2013. Melittin: a lytic peptide with anticancer properties. Environ. Toxicol. Pharmacol. 36: 697-705. DOI: 10.1016/j. etap.2013.06.009.

Garaj-Vrhovac V, Gajski G. 2009. Evaluation of the cytogenetic status of human lymphocytes after exposure to a high concentration of bee venom in vitro. Arh. Hig. Rada Toksikol. 60: 27-34. DOI: 10.2478/ 10004-1254-60-2009-1896.

Golstein P, Kroemer G. 2007. Cell death by necrosis: towards a molecular definition. Trends Biochem. Sci. 32: 37-43. DOI: 10.1016/j. tibs.2006.11.001.

Gordaliza M. 2007. Natural products as leads to anticancer drugs. Clin. Transl. Oncol. 9: 767-776. DOI: 10.1007/s12094-007-0138-9.

Habermann E. 1972. Bee and wasp venoms: The biochemistry and pharmacology of heir peptides and enzymes are reviewed. Science 177: 314-322.

Heinen TE, da Veiga AB. 2011. Arthropod venoms and cancer. Toxicon 57: 497-511. DOI: 10.1016/j.toxicon.2011.01.002.

Hider RC. 1988. Honeybee venom: a rich source of pharmacologically active peptides. Endeavour 12: 60-65. DOI: 10.1016/0160-9327(88)90082-8.

Holle L, Song W, Holle E, Wei Y, Wagner T, Yu X. 2003. A matrix metalloproteinase 2 cleavable melittin/avidin conjugate specifically targets tumor cells in vitro and in vivo. Int. J. Oncol. 22: 93-98.

Hong SJ, Rim GS, Yang HI, Yin CS, Koh HG, Jang MH, Kim CJ, Choe BK, Chung JH. 2005. Bee venom induces apoptosis through caspase-3 activation in synovial fibroblasts of patients with rheumatoid arthritis. Toxicon 46: 39-45. DOI: 10.1016/j.toxicon.2005.03.015.

Hoskin DW, Ramamoorthy A. 2008. Studies on anticancer activities of antimicrobial peptides. Biochim. Biophys. Acta 1778: 357-375. DOI: 10.1016/j.bbamem.2007.11.008.

Hu H, Chen D, Li Y, Zhang X. 2006. Effect of polypeptides in bee venom on growth inhibition and apoptosis induction of the human hepatoma cell line SMMC-7721 in-vitro and Balb/c nude mice in-vivo. J. Pharm. Pharmacol. 58: 83-89. DOI: 10.1211/jpp.58.1.0010.

Ip SW, Liao SS, Lin SY, Lin JP, Yang JS, Lin ML, Chen GW, Lu HF, Lin MW, Han SM, Chung JG. 2008a. The role of mitochondria in bee venominduced apoptosis in human breast cancer MCF7 cells. In Vivo 22: 237-245.

Ip SW, Wei HC, Lin JP, Kuo HM, Liu KC, Hsu SC, Yang JS, Mei-Dueyang, Chiu TH, Han SM, Chung JG. 2008b. Bee venom induced cell cycle arrest and apoptosis in human cervical epidermoid carcinoma $\mathrm{Ca}$ Ski cells. Anticancer Res 28: 833-842.

Ip SW, Chu YL, Yu CS, Chen PY, Ho HC, Yang JS, Huang HY, Chueh FS, Lai TY, Chung JG. 2012. Bee venom induces apoptosis through intracellular $\mathrm{Ca}$ (2+) -modulated intrinsic death pathway in human bladder cancer cells. Int. J. Urol. 19: 61-70. DOI: 10.1111/j.1442-2042.2011.02876.x.

Jang MH, Shin MC, Lim S, Han SM, Park HJ, Shin I. 2003. Bee venom induces apoptosis and inhibits expression of cyclooxygenase-2 mRNA in human lung cancer cell line NCl-H1299. J. Pharmacol. Sci. 91: 95-104. DOI: 10.1254/jphs.91.95.
Jin ZJ. 1980. Addition in drug combination. Acta Pharmacol. Sin. 1: 70-76. Jo M, Park MH, Kollipara PS, An BJ, Song HS, Han SB, Kim JH, Song MJ, Hong JT. 2012. Anti-cancer effect of bee venom toxin and melittin in ovarian cancer cells through induction of death receptors and inhibition of JAK2/STAT3 pathway. Toxicol. Appl. Pharmacol. 258: 72-81. DOI: 10.1016/j.taap.2011.10.009.

Kaufmann SH, Desnoyers S, Ottaviano Y, Davidson NE, Poirier GG. 1993. Specific proteolytic cleavage of poly(ADP-ribose) polymerase: an early marker of chemotherapy-induced apoptosis. Cancer Res. 53: 3976-3985.

Köberle B, Tomicic MT, Usanova S, Kaina B. 2010. Cisplatin resistance: preclinical findings and clinical implications. Biochim. Biophys. Acta 1806: 172-182. DOI: 10.1016/j.bbcan.2010.07.004.

Kwon YB, Lee HJ, Han HJ, Mar WC, Kang SK, Yoon OB, Beitz AJ, Lee JH. 2002. The water-soluble fraction of bee venom produces antinociceptive and anti-inflammatory effects on rheumatoid arthritis in rats. Life Sci. 71: 191-204. DOI: 10.1016/S0024-3205(02)01617-X.

Lariviere WR, Melzack R. 1996. The bee venom test: a new tonic-pain test. Pain 66: 271-277. DOI: 10.1016/0304-3959(96)03075-8.

Lazo JS, Hait WN, Kennedy KA, Braun ID, Meandzija B. 1985. Enhanced bleomycin-induced DNA damage and cytotoxicity with calmodulin antagonists. Mol. Pharmacol. 27: 387-393.

Lee YJ, Kang SJ, Kim BM, Kim YJ, Woo HD, Chung HW. 2007. Cytotoxicity of honeybee (Apis mellifera) venom in normal human lymphocytes and HL-60 cells. Chem. Biol. Interact. 169: 189-197. DOI: 10.1016/j. cbi.2007.06.036.

Leuschner C, Hansel W. 2004. Membrane disrupting lytic peptides for cancer treatments. Curr. Pharm. Des. 10: 2299-2310. DOl: 10.2174/ 1381612043383971.

Liu X, Chen D, Xie L, Zhang R. 2002. Effect of honey bee venom on proliferation of K1735M2 mouse melanoma cells in-vitro and growth of murine B16 melanomas in-vivo. J. Pharm. Pharmacol. 54: 1083-1089. DOI: 10.1211/002235702320266235.

Mehta RG, Pezzuto JM. 2002. Discovery of cancer preventive agents from natural products: from plants to prevention. Curr. Oncol. Rep. 4: 478-486. DOI: 10.1007/s11912-002-0059-2.

Mickisch G, Fajta S, Keilhauer G, Schlick E, Tschada R, Alken P. 1990. Chemosensitivity testing of primary human renal cell carcinoma by a tetrazolium based microculture assay (MTT). Urol. Res. 18: 131-136. DOI: $10.1007 / B F 00302474$.

Moon DO, Park SY, Heo MS, Kim KC, Park C, Ko WS. 2006. Key regulators in bee venom-induced apoptosis are $\mathrm{BCl}-2$ and caspase-3 in human leukemic U937 cells through downregulation of ERK and Akt. Int. Immunopharmacol. 6: 1796-1807. DOI: 10.1016/j.intimp.2006.07.027.

Nobili S, Lippi D, Witort E, Donnini M, Bausi L, Mini E, Capaccioli S. 2009. Natural compounds for cancer treatment and prevention. Pharmacol. Res. 59: 365-378. DOI: 10.1016/j.phrs.2009.01.017.

Osmak M. 1992. Collateral resistance or sensitivity of human larynx carcinoma HEp2 cells resistant to cis-dichlorodiammineplatinum (II) or vincristine sulfate. Neoplasma 39: 197-202.

Osmak M, Beketić-Orešković L, Matulić M, Sorić J. 1993. Resistance of human larynx carcinoma cells to cisplatin, gamma-irradiation and methotrexate does not involve overexpression of c-myc or c-Ki-ras oncogenes. Mutat. Res. 303: 113-120. DOI: 10.1016/0165-7992(93)90023-O.

Osmak M, Eljuga D. 1993. The characterization of two human cervical carcinoma HeLa sublines resistant to cisplatin. Res. Exp. Med. (Berl). 193: 389-396. DOI: 10.1007/BF02576247.

Oršolić N, Šver L, Verstovšek S, Terzić S, Bašić I. 2003. Inhibition of mammary carcinoma cell proliferation in vitro and tumor growth in vivo by bee venom. Toxicon 41: 861-870. DOl: 10.1016/S0041-0101(03)00045-X.

Oršolić N. 2009. Potentiation of bleomycin lethality in HeLa and V79 cells by bee venom. Arh. Hig. Rada Toksikol. 60: 317-326. DOI: 10.2478/ 10004-1254-60-2009-1936.

Oršolić N. 2012. Bee venom in cancer therapy. Cancer Metastasis Rev. 31: 173-194. DOI: 10.1007/s10555-011-9339-3.

Papo N, Shai Y. 2005. Host defense peptides as new weapons in cancer treatment. Cell. Mol. Life Sci. 62: 785-790. DOI: 10.1007/ s00018-005-4560-2.

Park MH, Choi MS, Kwak DH, Oh KW, Yoon do Y, Han SB, Song HS, Song MJ, Hong JT. 2011. Anti-cancer effect of bee venom in prostate cancer cells through activation of caspase pathway via inactivation of NF-KB. Prostate 71: 801-812. DOI: 10.1002/pros.21296.

Pérez-Tomás R. 2006. Multidrug resistance: retrospect and prospects in anti-cancer drug treatment. Curr. Med. Chem. 13: 1859-1876. DOI: $10.2174 / 092986706777585077$. 
Proskuryakov SY, Gabai VL. 2010. Mechanisms of tumor cell necrosis. Curr. Pharm. Des. 16: 56-68. DOI: 10.2174/138161210789941793.

Putz T, Ramoner R, Gander H, Rahm A, Bartsch G, Thurnher M. 2006. Antitumor action and immune activation through cooperation of bee venom secretory phospholipase A2 and phosphatidylinositol(3,4)-bisphosphate. Cancer Immunol. Immunother 55: 1374-1383. DOI: 10.1007/s00262-006-0143-9.

Raghuraman H, Chattopadhyay A. 2007. Melittin: a membrane-active peptide with diverse functions. Biosci. Rep. 27: 189-223. DOI: 10.1007/ s10540-006-9030-z.

Samadder P, Bittman R, Byun HS, Arthur G. 2004. Synthesis and use of novel ether phospholipid enantiomers to probe the molecular basis of the antitumor Effects of alkyllysophospholipids: correlation of differential activation of c-Jun $\mathrm{NH}(2)$-terminal protein kinase with antiproliferative effects in neuronal tumor cells. J. Med. Chem 47: 2710-2713. DOI: 10.1021/jm0302748.

Schweizer F. 2009. Cationic amphiphilic peptides with cancer-selective toxicity. Eur. J. Pharmacol. 625: 190-194. DOI: 10.1016/j.ejphar.2009.08.043.

Six DA, Dennis EA. 2000. The expanding superfamily of phospholipase A (2) enzymes: classification and characterization. Biochim. Biophys. Acta 1488: 1-19. DOI: 10.1016/S1388-1981(00)00105-0.

Son DJ, Lee JW, Lee YH, Song HS, Lee CK, Hong JT. 2007. Therapeutic application of anti-arthritis, pain-releasing, and anti-cancer effects of bee venom and its constituent compounds. Pharmacol. Ther. 115: 246-270. DOI: 10.1016/j.pharmthera.2007.04.004.
Stewart DJ. 2007. Mechanisms of resistance to cisplatin and carboplatin. Crit. Rev. Oncol. Hematol. 63: 12-31. DOI: 10.1016/j. critrevonc.2007.02.001.

Stuhlmeier KM. 2007. Apis mellifera venom and melittin block neither NFkappa B-p50-DNA interactions nor the activation of NF-kappa B, instead they activate the transcription of proinflammatory genes and the release of reactive oxygen intermediates. J. Immunol. 179: 655-664.

Tu WC, Wu CC, Hsieh HL, Chen CY, Hsu SL. 2008. Honeybee venom induces calcium-dependent but caspase-independent apoptotic cell death in human melanoma A2058 cells. Toxicon 52: 318-329. DOI: 10.1016/j.toxicon.2008.06.007.

Valentin E, Lambeau G. 2000. What can venom phospholipases $A(2)$ tell us about the functional diversity of mammalian secreted phospholipases A(2)? Biochimie 82: 815-831. DOI: 10.1016/S03009084(00)01168-8.

Varanda EA, Monti R, Tavares DC. 1999. Inhibitory effect of propolis and bee venom on the mutagenicity of some direct- and indirect-acting mutagens. Teratog. Carcinog. Mutagen. 19: 403-413. DOI: 10.1002/ (SICI) 1520-6866(1999)19:6<403::AID-TCM4>3.0.CO;2-2.

Zeh HJ 3rd, Lotze MT. 2005. Addicted to death: invasive cancer and the immune response to unscheduled cell death. J. Immunother. 28: 1-9.

Zisowsky J, Koegel S, Leyers S, Devarakonda K, Kassack MU, Osmak M, Jaehde U. 2007. Relevance of drug uptake and efflux for cisplatin sensitivity of tumor cells. Biochem. Pharmacol. 73: 298-307. DOI: 10.1016/j.bcp.2006.10.003. 